\title{
ASSESSMENT OF GROUNDWATER QUALITY FOR IRRIGATION PURPOSE IN MANAPPARAI BLOCK, TIRUCHIRAPALLI DISTRICT, TAMILNADU
}

\author{
REVATHY. $V^{1}$, SHANMUGASUNDRAM. $\mathbf{K}^{\mathbf{2}}$, LALITHA. $\mathbf{R}^{\mathbf{3}}$, NAGARAJAN $\mathbf{M}^{\mathbf{4}}$ \&SIVASUBRAMANIAN ${ }^{\mathbf{5}}$ \\ ${ }^{I}$ Research Scholar, Department of Soil and Water Engineering, AEC \& RI, TNAU, Kumulur, Trichy \\ ${ }^{2,3}$ Department of Soil and Water Engineering, AEC \& RI, TNAU, Kumulur, Trichy \\ ${ }^{4}$ Soil and Water Management Research Institute, Kattuthottam, Thanjavur \\ ${ }^{5}$ Department of Applied Sciences and Engineering, AEC \& RI, TNAU, Kumulur, Trichy
}

\begin{abstract}
Groundwater quality assessment is an important factor, to determine the suitability of water for irrigation use. Twenty-five groundwater samples were collected and calculated the various parameters, such as pH, EC, Cations (Calcium, Magnesium, Sodium and Potassium) and Anions (Chloride, Sulphate, Carbonate and Bicarbonate), using standard methods. The results of the concentrations were analysed with different irrigation indexes like EC, sodium percentage (SP), Sodium Adsorption ratio (SAR), Residual Sodium Carbonate (RSC), Permeability Index (PI) Magnesium Hazard Ratio (MH) and Kelly's Ratio (KR). Majority of index results such as SP, SAR, RSC, PI, MH and KR implying that, the 80 percent of the groundwater samples fall under excellent to good category and remaining 20 percent samples fall under poor condition. But, only based on EC, $80 \%$ of the samples fall under the high salinity category. Hence, the results were concluded that, the groundwater quality in the study area was suitable for irrigation purpose.

KEYWORDS: Groundwater Quality, Irrigation \& Quality Indexes
\end{abstract}

Received: Aug 19, 2017; Accepted: Sep 09, 2017; Published: Oct 05, 2017; Paper Id.: IJASROCT201759

\section{INTRODUCTION}

Groundwater is a vital natural resource, both in terms of water quality and yield. It is mainly used for drinking, agricultural and industrial purpose. Groundwater quality is controlled by both human and natural activities (Kouras et al., 2007). Due to increase in human population, the groundwater use for both irrigation and drinking purposes is mainly affected by various factors such as geology, land use practices, rainfall patterns and climatological factors. Particular in arid and semi arid regions, their natural ground water resources were used as poor quality of water, for irrigation (Reddy 2013). Poor quality of ground water may adversely affect the human health, soil physical conditions, plant growth and crop yields. Quality of irrigation water is vital for successful crop production and in addition, different crops require different irrigation water qualities. Therefore, testing and understanding the quality of ground water, used for irrigation will contribute the effective management and avoid the negative impacts on crop growth and its production. The hydro geochemical investigations of groundwater quality, with respect to irrigation purposes have been carried out and obtain the sufficient information on chemical weathering of rocks. The major irrigation water, is judged by four important measures of salinity hazard, sodium hazard, toxicity hazard and residual sodium carbonate hazard (Reddy 2013) and these parameters have been used to assess the suitability of groundwater, 
for irrigation purpose. Jain et al., (2012) assessed the quality of ground water in district Nanital in Uttarkhand, India, for irrigation purpose. In this present study, assessing the groundwater quality of Manapparai block, Tiruchirapalli district, is carried out, for using the groundwater in agriculture sector.

\section{MATERIALS AND METHODS}

In the present study, the ground water samples were collected from 25 different locations, within Manapparai block (Fig.1) during December 2016 in one liter PVC containers and later samples were analyzed, for differences Physiochemical parameters, such as pH, EC, Cations (Calcium, Magnesium, Sodium and Potassium) and Anions (Chloride, sulfate, Carbonate and Bicarbonate), by using standard methods mention in American public health association (ALPHA 1995). The $\mathrm{pH}$ and $\mathrm{EC}$ were measured by using $\mathrm{pH} \& \mathrm{EC}$ meters, respectively. Sodium $\left(\mathrm{Na}^{+}\right)$and Potassium $\left(\mathrm{K}^{+}\right)$were analyzed, by using a flame photometer. Calcium $\left(\mathrm{Ca}^{2+}\right)$ and Magnesium $\left(\mathrm{Mg}^{2+}\right)$ were estimated, by adopting Ethylenediaminetetraacetic acid (EDTA) titration, using Eriochrome black-T as an indicator. Carbonate and bicarbonate concentrations were measured by acid-base titration. The concentrations were interpreted and calculated, with irrigation indexes using the following formula of SP, SAR, RSC, PI and KR as follows:

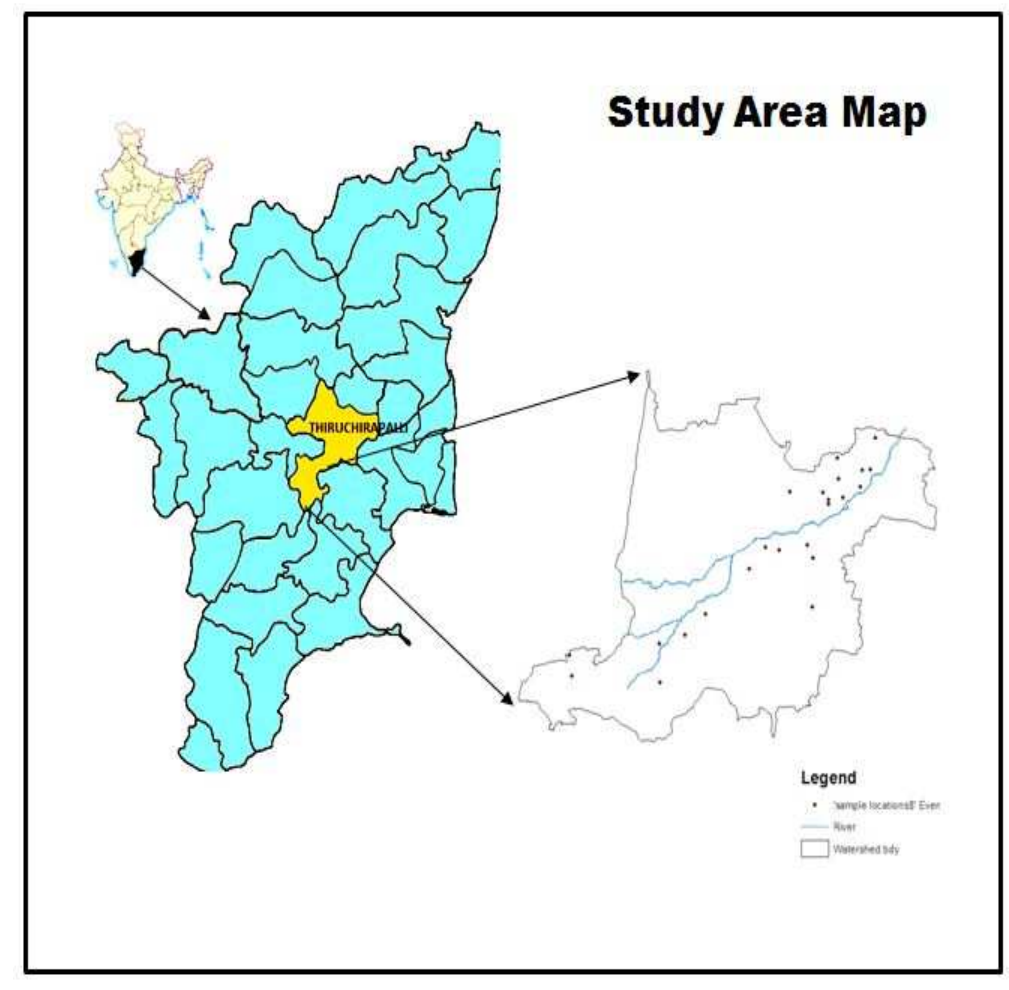

Figure 1: Location Map of Study Area

\section{Analytical Procedure}

\section{Sodium Percentage ( $\mathrm{Na} \%)$}

It is calculated by using the equation (Todd, 1995) as

$$
N a \%=\frac{\left[\left(N^{+}+K^{+}\right) \div\left(\mathrm{Ca}^{2+}+\mathrm{Mg}^{2+}+\mathrm{Na}^{+}+\mathrm{K}^{+}\right)\right]}{100}
$$


Concentrations are in milliequivalents per litre (meq/L).

\section{Sodium Absorption Ration (SAR)}

This was calculated employing the equation (Raghunath, 1987) as:

$S A R=\frac{N a^{+}}{\sqrt{\frac{C a^{2+}+M g^{2+}}{2}}}$

Concentrations are in milliequivalents per litre (meq/L).

\section{Residual Sodium Carbonate (RSC)}

This was calculated employing the equation (Eaton, 1950) as:

$$
R S C=\left[\left(\mathrm{CO}_{3}{ }^{2-}+\mathrm{HCO}_{3}{ }^{-}\right)-\left(\mathrm{Ca}^{2+}+\mathrm{Mg}^{2+}\right)\right]
$$

Concentrations are in milliequivalents per litre (meq/L).

\section{Permeability Index (PI)}

It was calculated by using the equation (Doneen (1964) as:

$$
P I=\frac{\left(\mathrm{Na}^{+}+\sqrt{\mathrm{HCO}}_{3}{ }^{-}\right)}{\left(\mathrm{Ca}^{2+}+\mathrm{Mg}^{2+}+\mathrm{Na}^{+}\right)} * 100
$$

Concentrations are in milliequivalents per litre (meq/L).

\section{Kelly's Ratio (KR)}

This was calculated employing the equation (Kelly, 1963) as

$\mathrm{KR}=\frac{\mathrm{Na}^{+}}{\left(\mathrm{Ca}^{2+}+\mathrm{Mg}^{2+}\right)}$

Concentrations are in milliequivalents per litre (meq/L).

\section{Magnesium Hazard Ratio (MH)}

The magnesium hazard $(\mathrm{MH})$ ratio values are calculated by using the equation proposed by Szabolcs and Darb (1964) for irrigation water where

$$
\mathrm{MH}=\frac{\mathrm{Mg}^{2+}}{\left(\mathrm{Ca}^{2+}+\mathrm{Mg}^{2+}\right)} \times 100
$$

The units are in milli equivalents per litre (meq/L).

\section{RESULTS AND DISCUSSIONS}

To understand the quality of groundwater in the present study area, twenty five groundwater samples were collected and analyzed. The Physio-chemical parameters of water samples are given in Table 1. The details of above mentioned irrigation quality parameters results are presented in Table 2. 
Table 1: Physico-Chemical Analysis of the Study Area

\begin{tabular}{|c|c|c|c|c|c|c|c|c|c|c|}
\hline Sl. No & Place & $\mathrm{pH}$ & $\mathrm{EC}$ & $\mathrm{Na}(\mathrm{meq} / \mathrm{l})$ & $\mathrm{Ca}(\mathrm{meq} / \mathrm{l})$ & Mg meq/l) & $\mathrm{K}(\mathrm{meq} / \mathrm{l})$ & $\mathrm{CO} 3(\mathrm{meq} / \mathrm{l})$ & $\mathrm{HCO} 3(\mathrm{meq} / \mathrm{l})$ & $\mathrm{Cl}(\mathrm{meq} / \mathrm{l})$ \\
\hline 1 & Alampattipudur & 7.1 & 430 & 0.82 & 4.40 & 0.42 & 0.10 & 1.20 & 0.71 & 1.63 \\
\hline 2 & Anankaraipatty & 7.8 & 710 & 2.84 & 2.50 & 2.83 & 0.74 & 2.00 & 3.30 & 4.03 \\
\hline 3 & Edayampatti & 7.4 & 850 & 2.19 & 3.70 & 3.08 & 0.08 & 3.19 & 3.09 & 4.31 \\
\hline 4 & Elamanur & 7.5 & 2000 & 7.91 & 4.40 & 8.41 & 0.18 & 2.00 & 5.23 & 6.42 \\
\hline 5 & Elangakurichi & 7.8 & 1510 & 2.28 & 4.25 & 3.17 & 0.18 & 1.60 & 3.37 & 0.37 \\
\hline 6 & K.Periappatti south & 6.9 & 640 & 0.52 & 2.00 & 1.08 & 0.03 & 3.21 & 3.54 & 3.52 \\
\hline 7 & K.puthukottai & 7.1 & 1070 & 5.50 & 3.00 & 28.16 & 0.31 & Nil & 3.90 & 5.24 \\
\hline 8 & Kalikattupatti & 7.7 & 910 & 2.49 & 3.90 & 2.42 & 0.33 & Nil & 4.61 & 6.62 \\
\hline 9 & Kalupati & 7.7 & 950 & 8.6 & 2.20 & 1.08 & 0.08 & 3.20 & 5.67 & 3.61 \\
\hline 10 & Karnampatti & 7.1 & 1790 & 8.04 & 3.70 & 1.67 & 0.08 & 2.00 & 2.10 & 7.01 \\
\hline 11 & Kasanur & 7.4 & 1100 & 4.47 & 4.00 & 3.75 & 0.03 & Nil & 2.39 & 3.94 \\
\hline 12 & Katumavatipuram & 7.7 & 980 & 4.34 & 3.90 & 3.25 & 0.28 & Nil & 4.99 & 5.72 \\
\hline 13 & Keranur & 7.3 & 910 & 7.48 & 2.10 & 0.42 & 0.03 & 2.40 & 5.70 & 4.31 \\
\hline 14 & Kumaravatti & 7.2 & 1640 & 4.52 & 3.50 & 6.66 & 0.10 & 2.10 & 5.78 & 3.35 \\
\hline 15 & Malaividipatty & 7.4 & 970 & 9.42 & 3.50 & 1.92 & 0.36 & 2.00 & 2.22 & 4.42 \\
\hline 16 & Mannaparai Town & 7.4 & 840 & 3.31 & 2.10 & 3.42 & 0.05 & 3.10 & 4.61 & 6.70 \\
\hline 17 & Maravanur & 7.3 & 1460 & 4.34 & 3.30 & 6.91 & 0.28 & Nil & 4.70 & 3.94 \\
\hline 18 & Metukalam & 7.6 & 1180 & 1.42 & 3.10 & 3.67 & 0.08 & 1.10 & 1.54 & 1.46 \\
\hline 19 & Muthappudaiyanppatti & 7.5 & 620 & 3.78 & 3.50 & 1.92 & 0.10 & Nil & 4.55 & 2.45 \\
\hline 20 & Natupatti & 7.3 & 1980 & 6.88 & 4.20 & 6.08 & 0.10 & Nil & 4.63 & 6.90 \\
\hline 21 & Pudur & 7.5 & 850 & 3.31 & 2.10 & 3.42 & 0.15 & Nil & 8.13 & 5.21 \\
\hline 22 & Sadaivampatti & 7.3 & 1310 & 6.28 & 4.05 & 9.41 & 0.05 & 2.00 & 4.44 & 4.96 \\
\hline 23 & Sathirappatti & 6.9 & 860 & 1.29 & 2.60 & 1.75 & 0.28 & 2.20 & 8.91 & 2.34 \\
\hline 24 & Seegampatti & 7.6 & 104 & 4.99 & 2.10 & 0.42 & 0.05 & 3.20 & 4.31 & 3.80 \\
\hline 25 & Utuppatti & 6.7 & 990 & 0.99 & 1.55 & 0.92 & 0.23 & Nil & 2.01 & 2.06 \\
\hline
\end{tabular}

\section{Total Salt Concentration}

As per IS: 11624-1986, the irrigation water quality rating can be classified based on the hazardous effects of total salt concentration expressed as electrical conductivity (EC) as shown in Table 2 and Fig 2. In the study area, 4 per cent groundwater samples have EC less than 250micromhos/cm i.e. low EC waters and 16 per cent samples have EC between 251-750 micromhos/cm categorized as medium class water. And remaining 80 per cent sample fall under EC 750-2250 micromhos/cm i.e. high EC waters.

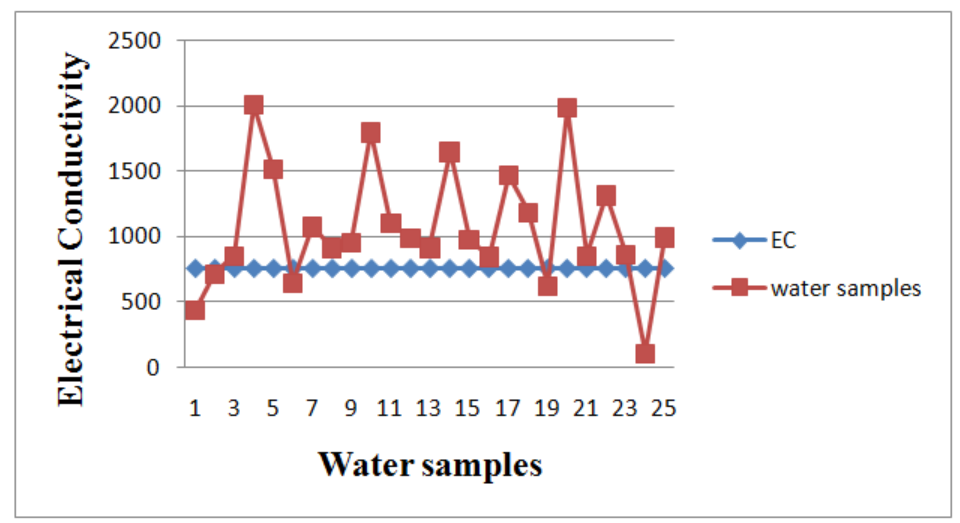

Figure 2: Graphical Representation for Electrical Conductivity

\section{Sodium Percentage (\% Na)}

It is an important factor in water quality for irrigation. High sodium in irrigation water use affects the plant growth and $\mathrm{Na}$ reacts with the soil to reduce its permeability (Joshi et al., 2009). The classification of sodium percentage is given by Wilcox (1985) shown in Table 2 and it indicates that 16 percent of samples fall under SP < 20 (Excellent), 52 per cent of samples fall under SP 20-40 (Good), 12 per cent of samples falls under SP 40-60 (Permissible) and remaining 20 per 
cent of samples indicating not suitable for irrigation (SP 60-80). Hence, results indicates that the overall groundwater quality of samples which are falling under excellent to good category.

Table 2: Classification of Groundwater on the Basis of EC, SP, SAR, RSC, KR and MH

\begin{tabular}{|c|c|c|}
\hline Classification Scheme & Caterogeries & Ranges \\
\hline \multirow{4}{*}{ Eeltrical Conductivity $(\mu \mathrm{S} / \mathrm{cm})$} & Low & $0-250$ \\
\hline & Medium & $251-750$ \\
\hline & High & $751-2250$ \\
\hline & Very high & $2251-6000$ \\
\hline \multirow{5}{*}{ Sodium Percentage (SP) (\%) } & Excellent & $<20$ \\
\hline & Good & $20-40$ \\
\hline & Permissible & $40-60$ \\
\hline & Doubtful & $60-80$ \\
\hline & Unsuitable & $>80$ \\
\hline \multirow{3}{*}{ Residual Sodium Concentration (RSC) (meq/l) } & Good & $<1.25$ \\
\hline & Medium & $1.25-2.5$ \\
\hline & $\mathrm{Bad}$ & $>2.5$ \\
\hline \multirow{4}{*}{ Sodium Adsorption Ratio (SAR) } & Low & $<10$ \\
\hline & Medium & $10-18$ \\
\hline & High & $18-26$ \\
\hline & Very high & $>26$ \\
\hline \multirow{3}{*}{ Permeability Index (PI) } & Class I & $>75$ \\
\hline & Class II & $25-75$ \\
\hline & Class III & $<25$ \\
\hline \multirow{2}{*}{ Kelly’s Ratio (KR) (meq/l) } & Safe & $<1$ \\
\hline & UnSafe & $>1$ \\
\hline \multirow{2}{*}{ Magnesium Hazard ratio (MH) } & Suitable & $<50$ \\
\hline & Unsuitable & $>50$ \\
\hline
\end{tabular}

\section{Sodium Adsorption Ratio (SAR)}

It gives the measure of groundwater suitable for irrigation, with respect to alkali hazard; excess sodium in water produces the undesirable effects of changing the soil properties and reducing soil permeability (Biswas et al., 2002). In the study area, all groundwater samples have SAR $<10$ indicates that within the excellent class (Table 3 \& Fig 3). 


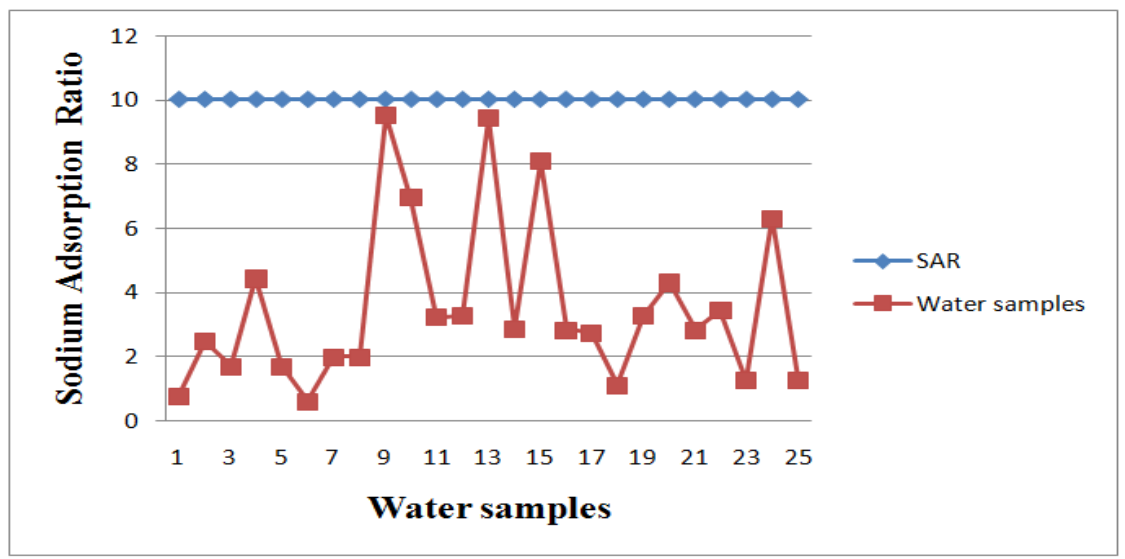

Figure 3: Graphical Representation for Sodium Adsorption Ratio

\section{Residual Sodium Carbonate (RSC)}

In the present study area, the calculated RSC values of ground water ranges from -27.26 to 6.76 meq/l (Table $3 \&$ Fig 4). Hence, 24 percent of groundwater samples indicating that, the RSC value is high (RSC > 2.5) and not suitable for irrigation and remaining 76 percent of samples falls under RSC $<1.25$ (Good category).

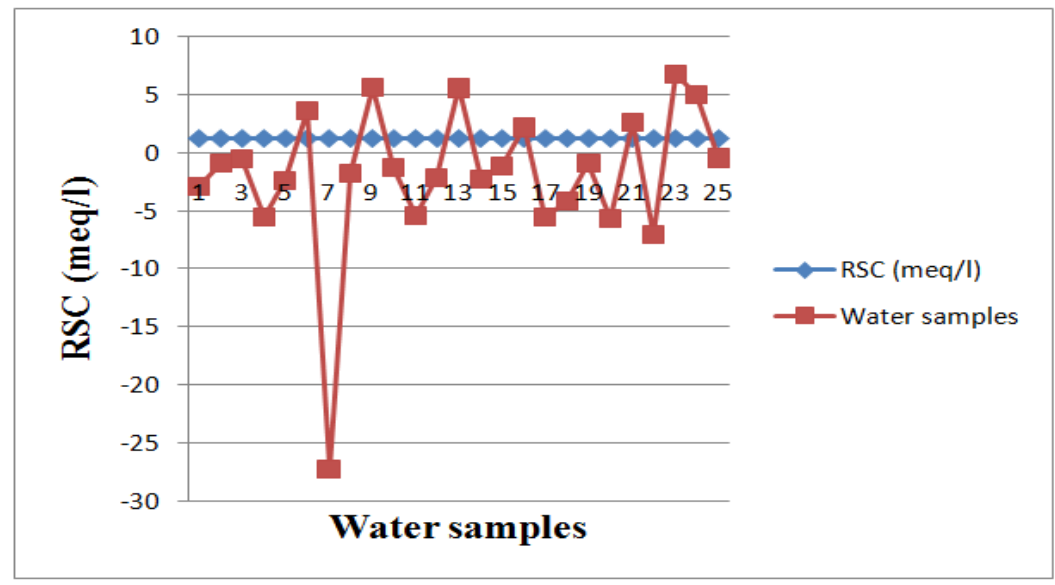

Figure 4: Graphical Representation for Residual Sodium Carbonate

\section{Permeability Index (PI)}

The permeability of soil is influenced by long term use of irrigation water containing sodium and bicarbonates. It can be classified into class I, Class II and Class III orders. Class I and Class II water was categorized as good and suitable for irrigation with 75 per cent or more maximum permeability. Class III water was unsuitable with less than 25 per cent of maximum permeability (Doneen, 1964; Raghunath, 1987). 


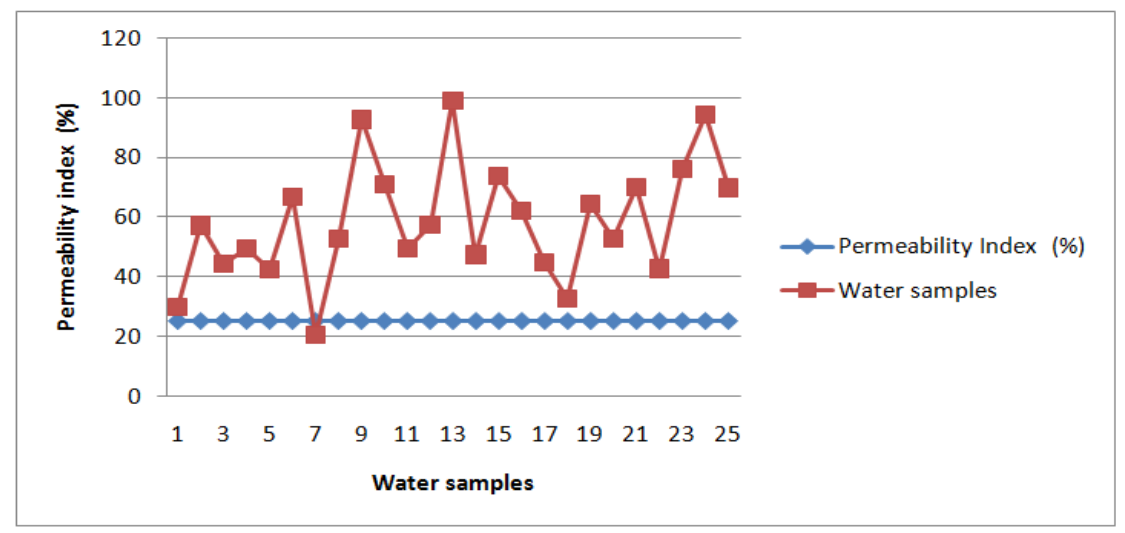

Figure 5: Graphical Representation for Permeability Index

In the present study area, the minimum and maximum permeability is 20.39 per cent and 98.68 per cent in Table 3 $\&$ Fig 5. Hence, the 96 per cent of groundwater samples fall under, suitable for irrigation and 4 per cent of groundwater sample fall in the class III category.

Table 3: Geochemical Characteristics of the Study Area

\begin{tabular}{|c|c|c|c|c|c|c|c|c|c|}
\hline Sl. No & Place & pH & EC & $\mathbf{S P}(\%)$ & SAR & RSC (Meq/l) & PI (\%) & KR(Meq/l) & MH (\%) \\
\hline 1 & Alampattipudur & 7.1 & 430 & 16.06 & 0.75 & -2.91 & 29.49 & 0.17 & 8.71 \\
\hline 2 & Anankaraipatty & 7.8 & 710 & 40.2 & 2.46 & -0.93 & 57 & 0.53 & 53.1 \\
\hline 3 & Edayampatti & 7.4 & 850 & 25.06 & 1.68 & -0.49 & 44.01 & 0.32 & 45.43 \\
\hline 4 & Elamanur & 7.5 & 2000 & 38.71 & 4.42 & -5.58 & 49.21 & 0.62 & 65.65 \\
\hline 5 & Elangakurichi & 7.8 & 1510 & 24.89 & 1.67 & -2.45 & 42.43 & 0.31 & 42.72 \\
\hline 6 & K.Periappatti south & 6.9 & 640 & 15.05 & 0.59 & 3.66 & 66.71 & 0.17 & 35.06 \\
\hline 7 & K.puthukottai & 7.1 & 1070 & 15.71 & 1.97 & -27.26 & 20.39 & 0.18 & 90.37 \\
\hline 8 & Kalikattupatti & 7.7 & 910 & 30.87 & 1.98 & -1.72 & 52.62 & 0.39 & 38.29 \\
\hline 9 & Kalupati & 7.7 & 950 & 72.57 & 9.5 & 5.59 & 92.43 & 2.62 & 32.93 \\
\hline 10 & Karnampatti & 7.1 & 1790 & 60.18 & 6.94 & -1.27 & 70.76 & 1.5 & 31.1 \\
\hline 11 & Kasanur & 7.4 & 1100 & 36.71 & 3.21 & -5.36 & 49.23 & 0.58 & 48.39 \\
\hline 12 & Katumavatipuram & 7.7 & 980 & 39.26 & 3.25 & -2.16 & 57.21 & 0.61 & 45.45 \\
\hline 13 & Keranur & 7.3 & 910 & 74.86 & 9.42 & 5.58 & 98.68 & 2.97 & 16.67 \\
\hline 14 & Kumaravatti & 7.2 & 1640 & 31.27 & 2.84 & -2.28 & 47.17 & 0.44 & 65.55 \\
\hline 15 & Malaiyidipatty & 7.4 & 970 & 64.34 & 8.09 & -1.2 & 73.52 & 1.74 & 35.42 \\
\hline 16 & Mannaparai Town & 7.4 & 840 & 37.85 & 2.82 & 2.19 & 61.8 & 0.6 & 61.96 \\
\hline 17 & Maravanur & 7.3 & 1460 & 31.16 & 2.72 & -5.51 & 44.73 & 0.43 & 67.68 \\
\hline 18 & Metukalam & 7.6 & 1180 & 18.11 & 1.09 & -4.13 & 32.49 & 0.21 & 54.21 \\
\hline 19 & Muthappudaiyanppatti & 7.5 & 620 & 41.74 & 3.25 & -0.87 & 64.27 & 0.7 & 35.42 \\
\hline 20 & Natupatti & 7.3 & 1980 & 40.45 & 4.29 & -5.65 & 52.63 & 0.67 & 59.14 \\
\hline 21 & Pudur & 7.5 & 850 & 38.55 & 2.82 & 2.61 & 69.78 & 0.6 & 61.96 \\
\hline 22 & Sadaiyampatti & 7.3 & 1310 & 31.99 & 3.42 & -7.02 & 42.49 & 0.47 & 69.91 \\
\hline 23 & Sathirappatti & 6.9 & 860 & 26.54 & 1.24 & 6.76 & 75.8 & 0.3 & 40.23 \\
\hline 24 & Seegampatti & 7.6 & 104 & 66.67 & 6.29 & 4.99 & 94.09 & 1.98 & 16.67 \\
\hline 25 & Utuppatti & 6.7 & 990 & 33.07 & 1.26 & -0.46 & 69.59 & 0.4 & 37.25 \\
\hline
\end{tabular}




\section{Kelly's Ratio (KR)}

Based on Kelly's ratios (Kelly, 1963) ground water was classified for irrigation, it is classified into safe $(<1)$ and unsafe $(>1)$. In the present study, 20 percent of the calculated value falls under samples not suitable for irrigation and remaining 80 per cent samples were suitable for irrigation shown in Table 3 \& Fig 6.

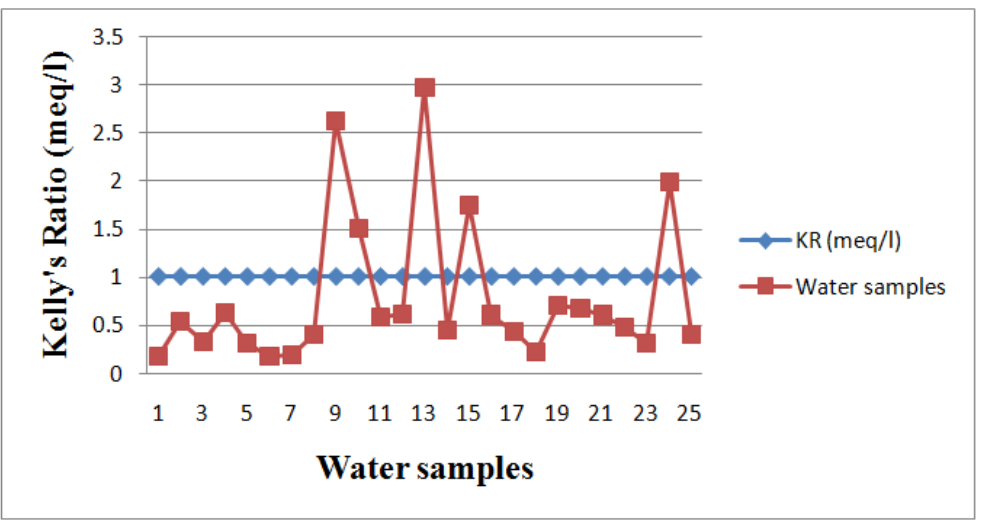

Figure 6: Graphical Representation for Kelly's Ratio

\section{Magnesium Hazard Ratio (MH)}

It is categorized into $\mathrm{MH}<50$ (suitable for irrigation) and $\mathrm{MH}>50$ (not suitable for irrigation and it adversely affects the plant growth). The computed values of MH for the study area are in between 8.71 to 90.37 percent in Table $3 \&$ Fig 7. About 60 per cent of the samples are suitable for irrigation $(\mathrm{MH}<50)$ and remaining 40 per cent sample are not suitable for irrigation $(\mathrm{MH}>50)$.

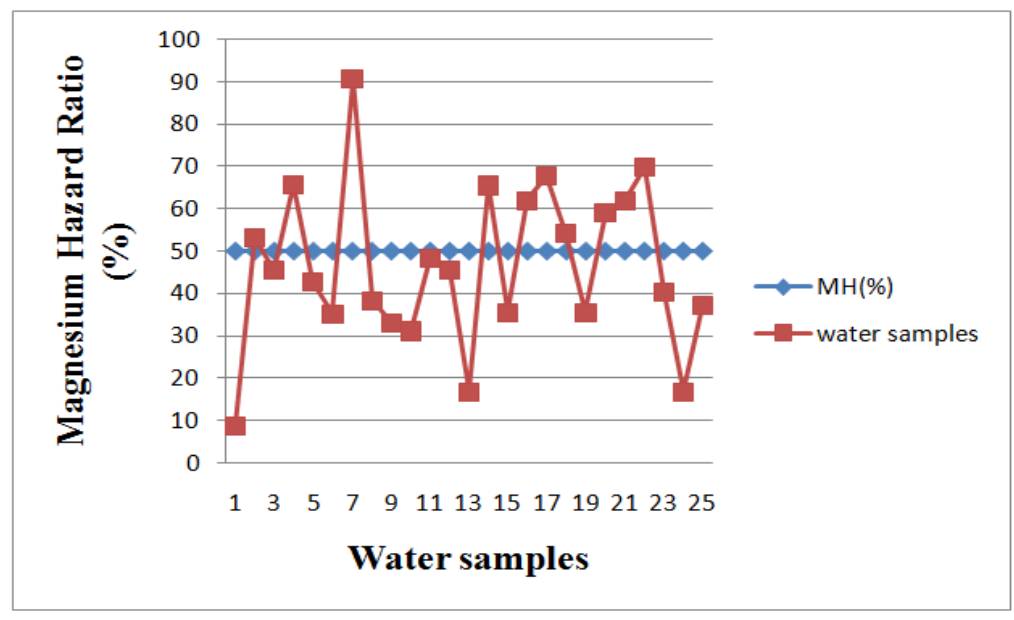

Figure 7: Graphical Representation for Magnesium Hazard

\section{CONCLUSIONS}

Evaluation of groundwater quality for irrigation were carried out using different index methods like SP, SAR, RSC, PI, KR and EC; among these, majority of index results were similar to the SP, SAR, RSC, PI, and KR is implying that the $80 \%$ of the groundwater samples fall under excellent to good category and remaining 20 per cent samples were falling under poor condition. But, only based on EC, $80 \%$ of the samples fall under the high salinity category (751 to 2250 
$\mu \mathrm{S} / \mathrm{cm})$; it is suitable for horticultural crops. Therefore, the results were concluded, that the study area groundwater quality was in general suitable for irrigation.

\section{REFERENCES}

1. Apha (1995). Standard method for the examination of water and wastewater (17th ed). Washington; APHA.

2. Biswas, S. N, Mohabey H, and Malik, M.L (2002). Assessment of the Irrigation Water Quality of River Ganga in Haridwar District. Asian J. Chem., 16.

3. Doneen, L. D (1964). Notes on Water Quality in Agriculture, Department of Water Science and Engineering, University of California, Water Science and Engineering, p. 400.

4. Eaton, F. M (1950). Significance of Carbonate in Irrigation Water. Soil Sci. 67:112-133.

5. Jain, C. K. Bandyopadhyay, A. and Bhadra, A. (2012) Assessment of ground water quality for irrigation purpose, District Nainital, Uttarakhand, India, Journal of Indian Water Resources Society, 32 :3-4.

6. Joshi, D. M, Kumar, A and Agrawal, N (2009). Assessment of the Irrigation Water Quality of River Ganga in Haridwar District India. J. Chem. 2(2):285-292.

7. R. Madhusudhan \& M. Inayathulla, Assessment of Groundwater Quality in and Around Bidadi Industrial Area, Ramanagar District, Karnataka, International Journal of Applied Engineering Research and Development (IJAPERD), Volume 5, Issue 1, January - February 2015, pp. 3-12

8. Kelly, W.P (1963). Use of Saline Irrigation Water. Soil Sci. 95(4):355-39.Michael AM (1978). Irrigation Theory and Practice. Vikas Publishing House Pvt.Ltd, New Delhi, pp. 713-713.

9. Kouras, A., Katsoyiannis, I and Voutsa, D. (2007) Journal Hazard. Mater, 147, 890-899.

10. Raghunath, H. M (1987). Groundwater, 2nd Ed. Wiley Eastern Ltd. New Delhi, India, pp. 344-369.

11. Reddy, S.K (2013) Assessment of groundwater quality for irrigation of Bhaskar Rao Kunta watershed, Nalgonda District, India, Vol 5(7), pp. 418-425, July 2013.

12. Szabolcs, I and Darb, C., (1964). "The influence of irrigation water of high sodium carbonate on soils", Proc. 8th Int. Cong. Of ISSS, Trans. II, pp. 803-12.

13. Todd DK (1995). Groundwater Hydrology. John Wiley and Sons Publications, 3rd Ed, New York.

14. Wilcox LV, Classification and used irrigation waters, U.S. Deptt, Agr. Crc, 1985, $969, \quad 19$. 
